EDITORIAL

\title{
Recognizing students' expertise and insights in expanding forms of academic writing and publishing about learning and teaching
}

\author{
Alison Cook-Sather, Bryn Mawr College, USA \\ *Mick Healey, University of Gloucestershire, and Healey HE Consultants, UK \\ Kelly E. Matthews, University of Queensland, Brisbane, Queensland, Australia
}

Contact: $\underline{\text { mhealey@glos.ac.uk }}$

Recognizing students as authors, reviewers, advisors, and editors in academic writing acknowledges students' expertise and the value of their unique perspectives. Integrating students into publishing practices, as we do in this journal, expands the sphere of student influence in the academy by structuring their expertise and insights into the development of knowledge about learning and teaching. In this editorial, we reflect on the role of students in IJSaP by sharing selected examples of how they are contributing to and creating scholarly conversations about students-as-partners work through their participation in the journal. This editorial is written by three faculty members of the editorial board and follows on from the editorial in the last issue that was written by five student members of the board (Ntem et al., 2020). Linking these affirmations of student contributions with a call for an expansion of writing genres to be inclusive of a greater number and a greater diversity of students (as well as staff/faculty/academics), we introduce a new section of the journal called Voices from the Field. Expanding IJSaP's commitment to inclusion, the focus of the inaugural version of this new section is on diversifying students-as-partners participants and practices.

\section{STUDENTS AS AUTHORS, REVIEWERS, ADVISORS, AND EDITORS}

When we launched IJSaP, one of our key commitments and guiding principles was to encourage and promote students as authors, reviewers, advisors, and editors (Cliffe et al., 2017). In the first four volumes of the journal (2017 to 2020), IJSaP has published the work of 377 authors, $44 \%$ of whom were students at the time of writing. In terms of reviewing, our policy is that peer-reviewed articles are reviewed by at least one student and one faculty member. In terms of advising, our International Advisory Group involves student members steering the direction of the journal. In the realm of editing, the IJSaP editorial board has had 16 student co-editors and eight faculty co-editors to date, and IJSaP is the only international teaching and learning journal of which we are aware that is fully co-edited by an even mix of students and faculty. Students are also involved in the publication process. Thus, students are present and participating in the strategic and the day-to-day work of IJSaP, drawing on their expertise and insights in a range of formal positions.

Having students in each of these roles changes both what we focus on and how. For instance, student co-editors and advisors identified problematic aspects of the term "students as partners" (Cook-Sather et al., 2018), and a student co-editor recommended 
that we include an open invitation on the website to the Voices from the Field section. Similarly, students shape the internal editorial conversations we have, consistently reminding all editors when our choices are useful as we engage as academics and when, conversely, we need to question rather than perpetuate accepted practices. Students' perspectives are necessarily different from staff and faculty perspectives by virtue of students' institutional positions and also because of the often greater diversity of their identities and the often wider range of their goals for the future.

\section{STUDENTS AS CONTRIBUTORS TO AND CREATORS OF SCHOLARLY CONVERSATIONS}

While students contribute to behind-the-scenes conversations about students as partners in learning and teaching in their roles as reviewers, advisors, and editors, as IJSaP authors, students contribute to public conversations and help to expand understandings of experiences of learning and teaching. For instance, Mariah Madigan, in conversation with a faculty and a staff co-author, unpacked her growing sense of agency through partnership in a conceptual article that reframed Cook-Sather, Bovill, and Felten's (2014) much-cited partnership themes of "respect, reciprocity, and responsibility in the more explicitly feminist terms of agency, accountability, and affinity" (Cates et al., 2018, p. 36). Using a different social-justice lens, Gagandeep Bindra, with seven student co-authors (2018), have raised important questions about inclusion in students-as-partners practices of marginalised students and students in the Global South, asking the IJSaP "community to think critically about its current practices as to who is involved in shaping the dialogue. Whose perspectives are missing?" (p. 12).

These two examples illustrate some of the ways in which students are shaping and shifting ongoing conversations about partnership in teaching and learning through publication. The calls for agency and inclusivity, highlighted in this article and opinion piece, inform conversations about students as partners in learning and teaching in powerful ways because they draw both on students' lived experiences and on students' analyses as legitimate contributions to knowledge about partnership and about learning and teaching.

\section{MORE WRITING GENRES DRAW A GREATER NUMBER AND A GREATER DIVERSITY OF STUDENT AUTHORS}

A key factor in attracting student authors, we argue, is the openness of IJSaP to different submission formats or genres. When we talk about genres, we mean the kind or form of writing chosen by an author, such as an empirical research article, a reflective essay, a conference paper, or a blog. We have argued elsewhere (Healey, Cook-Sather, \& Matthews, 2020; Healey, Matthews, \& Cook-Sather, 2019, 2020), as have Mercer-Mapstone and Abbot (2020), for the benefits of valuing a wide range of genres in writing about learning and teaching. Here we argue that valuing a wide range of genres is especially important for students.

The traditional or typical genres valued in most academic journals can feel "stuffy" to students (student quoted in Cook-Sather et al., 2019, p. 21). Rachel Guitman, Anita Acai, and Lucy Mercer-Mapstone (2020), who met as student partners, find "traditional" academic writing constraining. They have argued that "scholarly articles on higher education pedagogy and practice often require acknowledgments that bound, contextualize, warn against, and childproof what authors really want to say" (pp.61-62). Students are not alone in this view (see Helen Sword's [2009] writing on the banality of academic writing norms and April Baker-Bell's [2020] work on linguistic justice). For students who are not interested 
in pursuing a career in the academy, there is little impetus to learn to write in such genres, and for students whose language and identity are erased by such norms, having to use those norms in writing hinders students' expression and damages their sense of self. Yet, when students do not author in the academic literature, we lose out on the important knowledge and insights they have to offer, and our understanding of learning and teaching is compromised as a result.

When faced with the prospect of authoring a traditional academic piece of writing, some students can experience a strong feeling of imposter syndrome (Abbot, 2020). Alexander Dwyer (2018) contributed an opinion piece to IJSaP arguing that partnership opens new spaces and places for learning if enacted as a values-based practice. Reflecting on that writing experience, as a sole author stating a value judgement, he expressed doubt: "I did wonder if I was credible enough to have an opinion" (Dwyer, 2020, p. 209). He resolved this dilemma by focusing on "what was unique about my perspective" (Dwyer, 2020 , p. 209). This recognition of the unique perspective students have to offer is consistent with the potential (and often the expectation) that scholarship contributes a unique perspective, which, in the case of long-missing student perspectives, is a critical form of expertise. IJSaP exists in large part to counter the widely held notion-and the tendency of students to internalize it -that students' perspectives are not unique or important: they are both. Conversations about partnership "need to include genres that reflect and affirm the widest possible diversity of knowledges and voices" (Cook-Sather et al., 2020). It is essential that we recognize students as "legitimate authors and authorities on their higher education experiences" (Mercer-Mapstone \& Abbot, 2020, p. 237).

What is "credible enough"? Academic writing is entangled with questions of knowledge creation, what counts as knowledge, and who has the expertise to contribute to or create knowledge. Yahlnaaw (2019), an Indigenous person and (then) graduate student from Skidegate, Haida Gwaii, British Columbia, questioned in an IJSaP opinion piece the often unquestioned dominance of Western ways of knowing in students-as-partners practices and scholarship:

Academic work ... is often founded on the premise of objectivity and lack of bias. If we view our research and work as distanced from ourselves and therefore objective, how can we effectively engage in partnerships that are messy and relational? (p. 8)

To bring to life questions about what counts as knowledge as those questions relate to writing genres, Yahlnaaw shares a story of being invited to partner as a workshop cofacilitator on methods for learning and teaching research. When she shared her expertise on storytelling as a methodology, her co-facilitators described her approach as an "alternative" and "innovative." But she explains that, from her standpoint, "colonial knowledges came to this land after Indigenous knowledges. Thus, if anything is alternative, it's colonial knowledges because they came after" (Yahlnaaw, 2020, p. 105).

Genres that value the unique and subjective perspectives of individuals - the expertise they bring - as legitimate knowledge contributions open the door for more student authors and new forms of knowledge creation. The reflective writing genre is particularly conducive to engaging students in academic writing and publishing. Reflective forms of writing invite and provide space for students to create and contribute to academic writing because they "[feel] inherently inviting and engaging" (student quoted in CookSather et al., 2019, p. 22). Such invitations and spaces "give marginalized students more of a 
voice," as one student author has written: "It helps us realize that our voices matter, our stories matter, we matter" (quoted in Cook-Sather et al., 2019, p. 23).

We do not want to diminish genres already legitimated in the learning and teaching literature, such as empirical research articles or case studies of practices in Western contexts. As we have written elsewhere: "These genres enrich knowledge of learning and teaching in their own ways. Instead, we are arguing for also legitimating often unrecognized and equally important ways of contributing knowledge to the growing scholarship of teaching and learning in higher education" (Healey et al., 2020, p. 9). "Recognition," as Freya Aquarone and student co-authors (2020) have argued, is a social-justice concept focused on "recognising others as human, as equals, as esteemed and appreciated" (p. 23).

\section{INTRODUCING VOICES FROM THE FIELD}

Traditional peer-review processes can limit what and who is recognized. The goal of the Voices from the Field section of IJSaP is to diversify the voices engaged in dialogue about students-as-partners work. By creating a venue for a wide range of voices to address important questions around this work without going through the intensive time commitment required by the submission, review, and revision processes, we aim to recognize these voices and put them into dialogue with one another for the benefit of authors, readers, and the wider community of those writing about teaching and learning. While other sections of the journal present more expanded reflections on, opinions about, or analyses of students-as-partners work, Voices from the Field will shine lights on nascent efforts, projects that have been developed but not yet written about, and possibilities for future work.

To achieve these aims, the IJSaP editorial board proposed a future-focused and bigpicture question for the pilot section: "Over the next 3-5 years, how might students-aspartners work develop in a wider variety of contexts around the world and feature a greater diversity of experiences and voices?" Instead of working through the IJSaP system's lengthy submission process, authors were invited to submit 75-150-word responses either in an email sent to the editors or through an easy-to-use online form. The editors of this new section did not shepherd these contributions through the usual peer review process. Instead, they grouped the 28 responses they received into a set of related categories, all of which address this big-picture question under the title "Diversifying Students-as-Partners Participants and Practices." The purpose of this approach is simply to let these voices be heard and to enrich readers' thinking through their juxtaposition. The contributions to this section include 22 from students, 13 from academic staff/faculty, and five from professional staff/administrators from a variety of countries and regions (as named by contributors): Australia, Asia, Canada, China, Europe, Germany, Hong Kong, Papua New Guinea, Saudi Arabia, South America, the United Kingdom, and the United States. Of the 40 contributors, 19 (47\%) indicated that this was a first-time publishing experience.

While long accepted as necessarily rigorous, formal scholarly ways of writing may be "inadequate to the task of conveying the complex, incomplete, and messy aspects of the work" of teaching and learning (Cook-Sather et al., 2019, p. 14; Maurer, 2017). The new Voices from the Field section provides what we consider a space of affective rigor, demanding high levels of attention, respect, and learning keyed not to a single, uniform, and often exclusionary standard but rather informed by recognition of a diversity of identities, positions, and perspectives. This may be particularly important for potential student authors, most especially for student authors from marginalized backgrounds and in relation, 
as Yahlnaaw (2019) has noted, to Indigenous traditions of thinking and writing. For these reasons and more, it is particularly important that we expand ways students can create and contribute to conversations about partnership and about teaching and learning more generally.

\section{ACKNOWLEDGEMENTS}

We are grateful for the insightful comments we received on a draft of this editorial from Sophia Abbot (George Mason, USA), Ben Moorhouse (Hong Kong Baptist University), Sarah Slates (Bryn Mawr, USA), and Harry West (University of West of England).

\section{NOTE ON CONTRIBUTORS}

Alison Cook-Sather is Mary Katharine Woodworth Professor of Education at Bryn Mawr College and Director of the Teaching and Learning Institute at Bryn Mawr and Haverford Colleges, USA.

Mick Healey is a higher education consultant and researcher at Healey HE Consultants. He is also an Emeritus Professor at the University of Gloucestershire, UK.

Kelly Matthews is an Associate Professor in Higher Education at the University of Queensland, Australia.

\section{REFERENCES}

Abbot, S. (2020). Reflection 7.2. Acknowledging imposter syndrome. In M. Healey, K. E. Matthews, \& A. Cook-Sather, Writing about learning and teaching in higher education: Creating and contributing to public scholarly conversations across a range of genres (p. 73). Center for Engaged Learning Open-Access Books, Elon University. https://www.centerforengagedlearning.org/books/writing-about-learning/

Aquarone, F., Nehéz-Posony, L., Anwar, P. R., Salam, S., Koutsouri, E., Kim, M., Suh, S., Mayomi, T., Pilarska, J., Houghton, E., \& Boodai, Y. (2020). 'We're trying to do things differently': The challenges of relationships and recognition in Higher Education. Centre for Public Policy Research (CPPR), King's College London. https://www.kcl.ac.uk/ecs/assets/were-trying-to-do-things-differently-ebook.pdf

Baker-Bell, A. (2020). Linguistic justice: Black language, literacy, and pedagogy. Routledge. Bindra, G., Easwaran, K., Firasta, L., Hirsch, M., Kapoor, A., Sosnowski, A., Stec-Marksman, T., \& Vatansever, G. (2018). Increasing representation and equity in students as partners initiatives. International Journal for Students as Partners, 2(2), 10-15. https://doi.org/10.15173/ijsap.v2i2.3536

Cates, R. M., Madigan, M. R., \& Reitenauer, V. L. (2018). "Locations of possibility": Critical perspectives on partnership. International Journal for Students as Partners, 2(1), 3346. https://doi.org/10.15173/ijsap.v2i1.3341

Cliffe, A., Cook-Sather, A., Healey, M., Healey, R., Marquis, E., Matthews, K. E., MercerMapstone, L., Ntem, A., Puri, V., \& Woolmer, C. (2017). Launching a journal about and through students as partners. International Journal for Students as Partners, 1(1). https://doi.org/10.15173/ijsap.v1i1.3194 
Cook-Sather, A., Abbot, S., \& Felten, P. (2019). Legitimating reflective writing in SoTL: "Dysfunctional illusions of rigor" revisited. Teaching \& Learning Inquiry, 7(2), 14-27. https://doi.org/10.20343/teachlearninqu.7.2.2

Cook-Sather, A, Bovill, C, \& Felten, P (2014). Engaging students as partners in teaching \& learning: A guide for faculty. Jossey-Bass.

Cook-Sather, A., Healey, M., \& Matthews, K. E. (2020, September 18). Writing about learning and teaching in precarious and promising times. Association of American Colleges and Universities Liberal Education Blog. https://www.aacu.org/blog/writingabout-learning-and-teaching-precarious-and-promising-times

Cook-Sather, A., Matthews, K. E., Ntem, A., \& Leathwick, S. (2018). What we talk about when we talk about students as partners. International Journal for Students as Partners, 2(2), 1-9. https://doi.org/10.15173/ijsap.v2i2.3790

Dwyer, A. (2018). Toward the formation of genuine partnership spaces. International Journal for Students as Partners, 2(1), 11-15. https://doi.org/10.15173/ijsap.v2i1.3503

Dwyer, A. (2020). Reflection 19.1. The experience of writing an opinion piece. In M. Healey, K. E. Matthews, \& A. Cook-Sather, Writing about learning and teaching in higher education: Creating and contributing to public scholarly conversations across a range of genres (p. 209). Center for Engaged Learning Open-Access Books, Elon University. https://www.centerforengagedlearning.org/books/writing-about-learning/

Guitman, R., Acai, A., \& Mercer-Mapstone. L. (2020). Unlearning hierarchies and striving for relational diversity: A feminist manifesto for student-staff partnerships. In L. MercerMapstone, \& S. Abbot (Eds.), The power of partnership: Students, staff, and faculty revolutionizing higher education (pp. 61-72). Center for Engaged Learning OpenAccess Books, Elon University. http://www.centerforengagedlearning.org/books/power-of-partnership/chapter-3/

Healey, M., Cook-Sather, A., \& Matthews, K. E. (2020). Expanding the conventional writing genres: A matter of equity and inclusion. Educational Developments, 21(3), 8-11 https://www.seda.ac.uk/ed-devs-2020

Healey, M., Matthews, K. E., \& Cook-Sather, A. (2019). Writing scholarship of teaching and learning articles for peer-reviewed journals. Teaching \& Learning Inquiry, 7(2), 2850. https://doi.org/10.20343/teachlearninqu.7.2.3

Healey, M., Matthews, K. E., \& Cook-Sather, A. (2020). Writing about learning and teaching in higher education: Creating and contributing to public scholarly conversations across a range of genres. Center for Engaged Learning Open-Access Books, Elon University. https://www.centerforengagedlearning.org/books/writing-aboutlearning/

Maurer, T. (2017). Guidelines for authorship credit, order, and co-inquirer learning in collaborative faculty-student SoTL projects. Teaching \& Learning Inquiry, 5(1). http://dx.doi.org/10.20343/teachlearninqu.5.1.9

Mercer-Mapstone, L., \& Abbot, S. (2020). Things that make us go hmmm. In L. MercerMapstone \& S. Abbot (Eds.), The power of partnerships: Students, staff, and faculty revolutionizing higher education. Center for Engaged Learning Open-Access Books, Elon University. https://www.centerforengagedlearning.org/books/power-ofpartnership/conclusion/

Ntem, A., Ngyuen, E., Rafferty, C., Kwan, C., \& Benlahcene, A. (2020). Students as partners in crisis? Student co-editors' perspectives on COVID-19, values, and the shift to virtual 
spaces. International Journal for Students as Partners, 4(2), 1-8.

https://doi.org/10.15173/ijsap.v4i2.4432

Sword, H. (2009). Writing higher education differently: A manifesto on style. Studies in Higher Education, 34(3), 319-336. https://doi.org/10.1080/03075070802597101

Yahlnaaw. (2019). T'aats'iigang - Stuffing a jar full. International Journal for Students as Partners, 3(2), 6-10. https://doi.org/10.15173/ijsap.v3i2.4081

Yahlnaaw. (2020). Reflection 11.1. Experience of different presentation genres. In M. Healey, K. E. Matthews, \& A. Cook-Sather, Writing about learning and teaching in higher education: Creating and contributing to public scholarly conversations across a range of genres (p. 105). Center for Engaged Learning Open-Access Books, Elon University. https://www.centerforengagedlearning.org/books/writing-aboutlearning/ 